Rev. Elev. Méd. Vét. Pays trop., 1968, 21, 3 (297-308).

\title{
Aspects biologiques de la multiplication du virus de la peste des petits ruminants ou PPR sur les cultures cellulaires ${ }^{(*)}$
}

\author{
par A. LAURENT
}

\begin{abstract}
RÉSUMÉ
L'effet cytopathogène du virus PPR se traduit par des syncytıums, des inciusions nuclécires et cytoplasmıques sur des cellules de dıfférentes origines. II est inactivé par l'éther et à pH 3. Sa synthèse n'est pas bloquée par la 5-iodo-déoxyuridine. Sa structure étudiée ou microscope électronique est semblable à celle du virus de la peste bovine, quorque son diamètre soit plus grand. La morphologie de sa multiplicatıon examinée au microscope électronique n'a pas permis de connaître son mode de pénétration, mais la sortie se fait par le bourgeonnement de la membrane cellulaire. Son étude, du point de vue cyto-chimique permet de suppaser qu'il effectue un transit par le nucléole, et que les inclusions nucléaires et cytoplasmiques sont formées d'ARN. L'ensemble des résultats obtenus définit le virus PPR comme un Paramyxovirus et amène des hypothèses intéressant son cycle de multiplication.
\end{abstract}

La peste des petits ruminants ou PPR, rencontrée dans les pays de l'Ouest africain est une maladie contagıeuse atteıgnant les chèvres et les moutons. Elle se traduit par une fièvre élevée, l'apparition au niveau des muqueuses buccales et laryngées d'ulcérations suivie d'une violente diarrhée. Elle se termine le plus souvent par la mort des animaux dans un état de profond abattement.

Cette maladie due à un virus, a été décrite en 1942 par GARGADENNEC et LALANNE qui l'ont observée au Dahomey et en Côted'lvoire, puis en 1956 par MORNET, ORUE et coll., la maladie ayant sévi au Sénégal de 1956 à 1962. Elle a été rencontrée également au Nigeria en 1958 (JOHNSON).

MORNET, ORUE et coll. (1956) ont montré son étiologie pestique, GILBERT et MONNIER (1962) ont adapté le virus responsable aux cul-

*) Travail extrait du Diplôme d'Eludes Supérieures de Zoologie, soutenu par Madame Annie Laurent le 31 octobre 1967 à la Faculté des Sciences de l'Université de Dakar. tures cellulaires de rein d'embryon de mouton: ces mêmes auteurs (1963) par des expériences d'immunologie croisée ont mis en évidence l'identité sérologique du virus bovipestique et du virus PPR.

En complément des travaux précédents, il a paru intéressant d'étudier :

- son effet pathogène sur différentes cellules,

- ses propriétés physico-chimiques,

- l'aspect morphologique et cytochimique de sa multiplication.

L'ensemble des résultats obtenus a conduit à une meilieure connaissance de cet agent pathogène et a permis son intégration dans la classification moderne des virus.

\section{I. - EFFET CYTOPATHOGĖNE DU VIRUS PPR.}

\section{A) Matériel et méthodes.}

Virus : le virus est un $7 \mathrm{e}$ passage sur cellules rénales d'embryon de mouton, de la suspension 
virulente obtenue par GILBERT et MONNIER (1962) à partir du sang défibriné d'un mouton atteint spontanément de peste. Ce 7 e passage titre $10^{5,3}$ DICT $50 / \mathrm{ml}$ calculées selon la méthode des totaux cumulatifs de Reed ef Muench (1938).

Les cultures cellulaires : on a utılisé soit des cellules de première explantation soit des cellules de lignée continue.

Cellules de première explantation : elles ont été obtenues en survant la technique mise au point par PLOWRIGHT et FERRIS (1956), pour la culture des cellules rénales d'embryon de veau. Cette technıque a également été employée pour les reins d'embryon de chèvre et de mouton, l'amnios humain et les reins de singe adulte. Leur milieu de croissance est constitué par du HANKS LAYE.

Cellules de lignée contınue : le virus PPR a été cultivé sur les souches cellulaires suivantes :

- la souche MDBKC ; établie par MADIN et DARBY (1958), elle provient de cellules de rein de bovin adulte.

- la souche MS; elle provient d'un rein de singe adulte. Elle a été établie par l'Institut Intern. de la Santé de Tokyo (OZAWA, 1967).

- la souche BHK 21 ; elle provient d'un rein de hamster âgé de 5 jours. Elle a été établie en 1961 par STOKER et MacPHERSON. Les cellules de lignée continue sont mises en culture dans du EARLE auquel on ajoute des acides aminés et de l'extrait de levure, dit EARLE «croissance» (BOURDIN ef BERNARD, 1967). Pour la mise en culture de tous les types de cellules, 10 p. 100 de sérum de veau sont ajoutés au milieu; ils sont remplacés par 2 p. 100 de sérum de bœuf aux changements de milieu.

Les cellules sont réparties en tubes à lamelle, ce qui en permet l'examen après fixation ef coloration. Les cellules sont cultivées à la température de $37 \mathrm{o} C$; elles mettent 24 heures pour se fixer sur le verre, 48 heures pour recouvrir la lamelle d'un tapis cellulaire. C'est à ce moment qu'elles sont inoculées à raison de $0,2 \mathrm{ml}$ par tube de suspension virulente.

Virus et cellules sont laissés en contact 30 minutes à la température ambiante, puis un milieu neuf est remis. Lorsque les lésions apparaissent, vers le $6 \mathrm{e}$ ou $7 \mathrm{e}$ jour et que l'effet cytopathogène est net, les lamelles sont extraites des tubes, fixées au Bouin alcoolique, colorées à l'hémalun-éosine et montées sur lames.

\section{B) Résultats.}

1) Cellules de rein d'embryon de mouton:

GILBERT et MONNIER (1962) ont décrit l'effet pathogène du virus PPR sur ces cellules. A partir du 6 e ou 7 e jour, se constituent de grands syncytiums dont les noyaux se disposent en couronne autour d'une zone centrale circulaire ou ovoide fortement éosınophile. Les noyaux de ces cellules contiennent ou non des inclusions éosinophiles comme les inclusions cytoplasmiques qui se regroupent autour de la couronne de noyaux. Cet aspect caractéristique des lésions de PPR se retrouve pour les cellules de rein d'embryon de veau (Fig. 1), de rein d'embryon de chèvre (Fig. 2) et de rein de singe (Fig. 3). Il diffère sur cellules d'amnios humain ou les noyaux peu nombreux sont groupés au centre du syncytium (Fig. 4).

\section{2) Cellules de lignée continue :}

L'effet cytopathogène du virus PPR est faible et moins caractéristique. Dans les cellules MDBKC (Fig. 5) et MS (Fig. 6), les inclusions nucléaires sont plus nombreuses que dans les cellules BHK 21. Celles-ci présentent des syncytiums de forme très allongée (Fig. 7).

\section{II. - PROPRIÉTÉS CHIMIQUES}

\section{A) Inactivation par l'éther.}

Une suspension de virus PPR en HANKS LAYE, titrant $10^{6,3}$ DICT 50 est distribuée dans deux béchers à large ouverture. Dans I'un, on ajoute 20 p. 100 d'éther, dans l'autre 20 p. 100 d'eau distillée et après agitation les deux béchers sont laissés à $+4^{\circ} \mathrm{C}$. Au bout de 12 heures, le mélange éther-virus est soumis à l'action du vide pendant 30 minutes. Enfin les deux solutions sont titrées sur cultures cellulaires. Les titres finals sont : nul pour le virus traité par l'éther sans changement pour le virus non traité.

\section{B) Action du $\mathrm{pH}$.}

Dans deux erlenmeyers, on distribue $9 \mathrm{ml}$ de milieu de Eagle à $\mathrm{pH} 3$, dans I'un, et $9 \mathrm{ml}$ de milieu de Eagle à pH 7,4 dans l'autre. Dans 


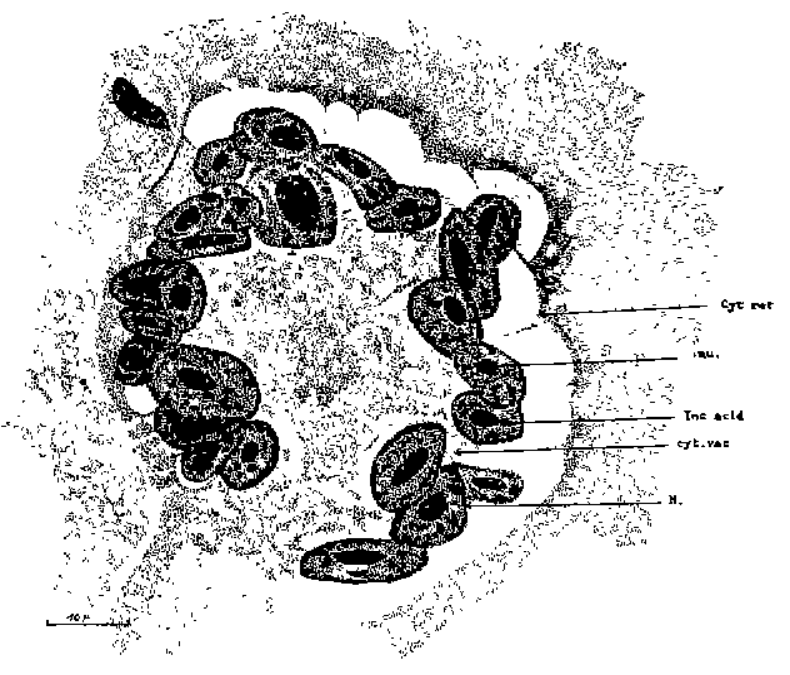

Fig. 1. - Polycaryocyte sur cellules rénales d'embryon de veau.

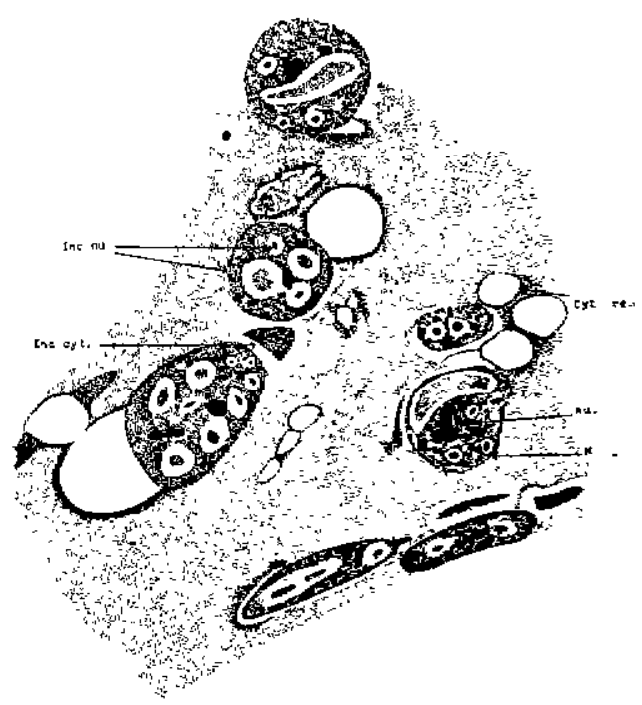

Fig. 3. - Polycaryocyte sur cellules rénales de singe.

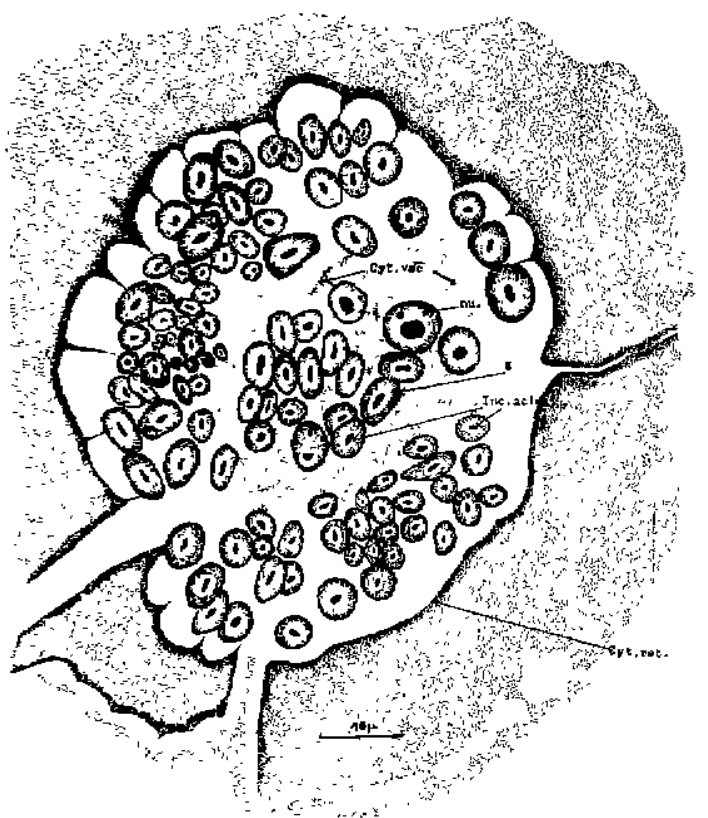

Fig. 2. - Polycaryocyte sur cellules rénales d'embryon de chèvre.

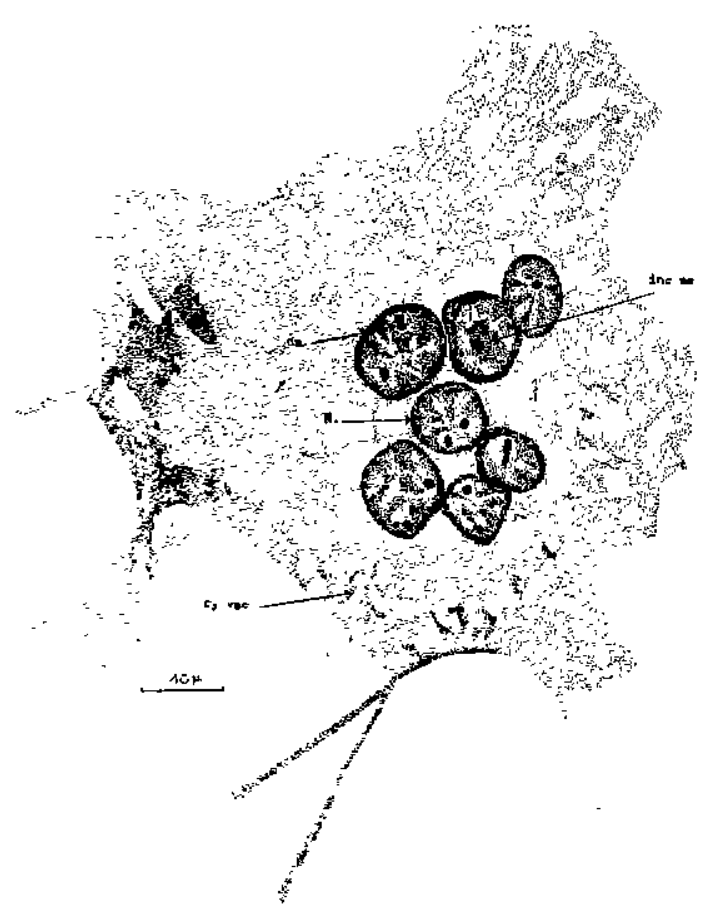

Fig. 4, - Polycaryocyte sur cellules d'amnios humain. 


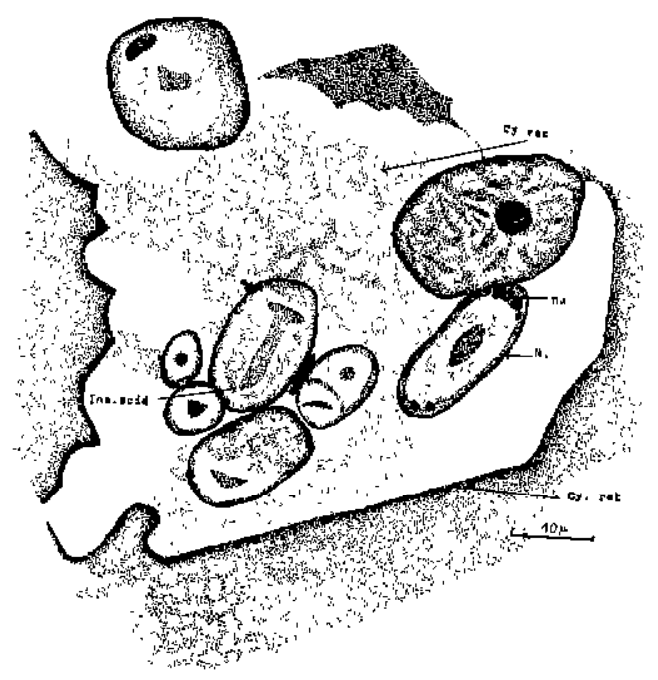

Fig. 5. - Polycaryocyte sur cellules MDBKC.

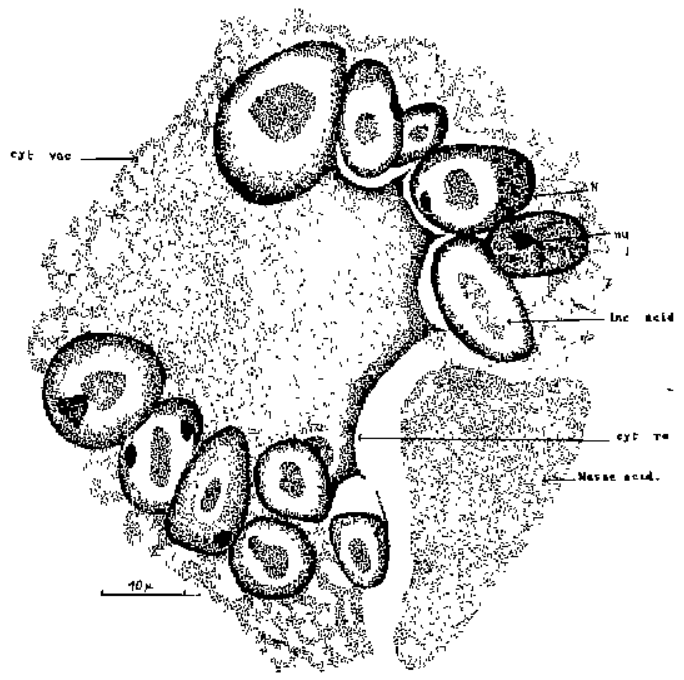

Fig. 6. - Polycaryocyte sur cellules MS.

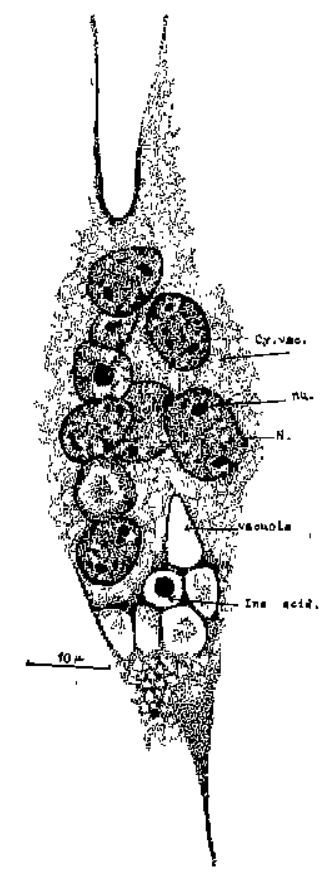

Fig. 7. - Polycaryocyte sur cellules BHK 21. 
chacun, on ajoute $1 \mathrm{ml}$ de suspension virulente titrant 105,5 DICT 50. Ces deux mélanges sont laissés 3 heures à la température ambiante puis titrés. Le résultat du titrage montre que le virus est inactivé à $\mathrm{pH} 3$.

\section{C) Action des pyrimidines halogénées.}

On prépare une solution mère d'IDU à $10^{-3} \mathrm{M}$ (cette solution contient $354 \mathrm{mg}$ d'IDU p. 1.000).

Des tubes à lameiles contenant une culture de rein d'embryon de mouton âgée de 48 heures, sont inoculés avec un $7 \mathrm{e}$ passage du virus PPR. Une partie des tubes reçoit l'IDU à la concentration de $10^{-5} M_{1} c^{\prime}$ est-à-dire $1 \mathrm{ml}$ de la solution à $10^{-3} \mathrm{M}(\mathrm{II})$; une autre partie reçoit l'IDU à la concentration de $10^{-6} \mathrm{M}$, c'est-d̀-dire $0.1 \mathrm{ml}$ de la solution d̀ $10^{-3} M$ (III). Le reste des tubes est inoculé normalement (1).

Les liquides virulents I, II et III sont récoltés et titrés sur cultures cellulaires :
(l) $: 10^{4,2}$
(II) $: 10^{3,5}$
(III) $: 10^{3,2}$.

Ces résultats montrent aux erreurs d'expérience près, que la synthèse du virus PPR n'est pas bloquée par l'IDU et qu'il est un virus à ARN par conséquent.

\section{III. - ASPECT MORPHOLOGIQUE DE LA MULTIPLICATION DU VIRUS PPR AU MICROSCOPE ÉLECTRONIQUE}

\section{A) Structure du virus PPR :}

L'étude du virus PPR en coloration négative au microscope électronique a fait l'objet d'une publication (BOURDIN ef LAURENT, 1967). Elle a permis d'observer que les particules virales de PPR ont une structure semblable à celle des Paramyxovirus : une membrane hérissée de projections à l'intérieur de laquelle s'enroule un filament hélicoidal formé d'acide ribonucléique entouré de protéines, la nucléocapside. Ces particules grossièrement sphériques ont une taille qui varie de 1.500 à $8.000 \AA$ avec une majorité nette de particules de grande taille $(5.000$ à $8.000 \AA)$. Le diamètre du filament hélicoïdal est en moyenne de $180 \AA$.

\section{B) Multiplication du virus PPR :}

I) Matériel ef méthodes.

Pour ce travail, le virus PPR a été cultivé sur cellules de rein d'embryon de mouton dans les flacons de $60 \mathrm{ml}$ de type «mexicain». Ces cellules inoculées ont été fixées à des temps variables après l'inoculation au tétroxyde d'osmium à 1 p. 100 en tampon Milloning. Une ouverture rectangulaire a été pratiquée sur la face des flacons opposée au tapis cellulaire. Les capsules de gélatine emplies d'Epon 812 ont été renversées sur les cellules. Après polymérisation, les capsules sont décollées à l'aide de neige carbonique et débitées en coupes ultra-fines qui sont déposées sur des grilles carbonées et colorées à l'acétate d'uranyle. Le microscope électronique est un appareil de type OPL (*).

\section{2) Résuitats.}

Les examens de cellules de mouton inoculées ef fixées à différents temps n'ont pas permis d'élucider le cycle de multiplication du virus, en particulier son mode de pénétration dans la cellule. En ce qui concerne les Myxovirus et les Paramyxovirus myxophiles, DALES ef CHOPPIN (1962) pour l'Influenza et COMPANS et coll. (1966) pour le Para-Influenza ont observé que ces deux virus pénétraient dans la cellule par le phénomène de pinocytose. A la suite de ce processus, les particules virales sont englobées en entier dans des vacuoles cytoplasmiques où elles se désintègrent rapidement pour finclement disparaître dans la masse cytoplasmique. Ce phénomène se prodult dans la demi-heure qui suit l'inoculation.

Quant au virus PPR, on note simplement que les particules virales semblent s'accoler à la membrane cellulaire entre la $10^{\mathrm{e}}$ et la $30^{\mathrm{e}}$ minute (photo $\Pi^{\circ}$ I). A partir de cette époque, il n'est pas possible de retrouver de forme virale à l'intérıeur des cellules infectées. Cette phase correspond à la pérıode d'éclipse qui s'étend de la $2^{e}$ à la $6^{\mathrm{e}}$ heure. Après cette phase, on constate que l'ergastoplasme subit d'importantes transformations caractérisées par l'abondance des ribosomes (photo no 2). Ce phénomène a été

(*) Nous prions Monsieur le Professeur BOISSON et ses collaborateurs de trouver ici l'expression de toute notre grafitude pour les facilités de travail qu'ils nous ont accordées. 


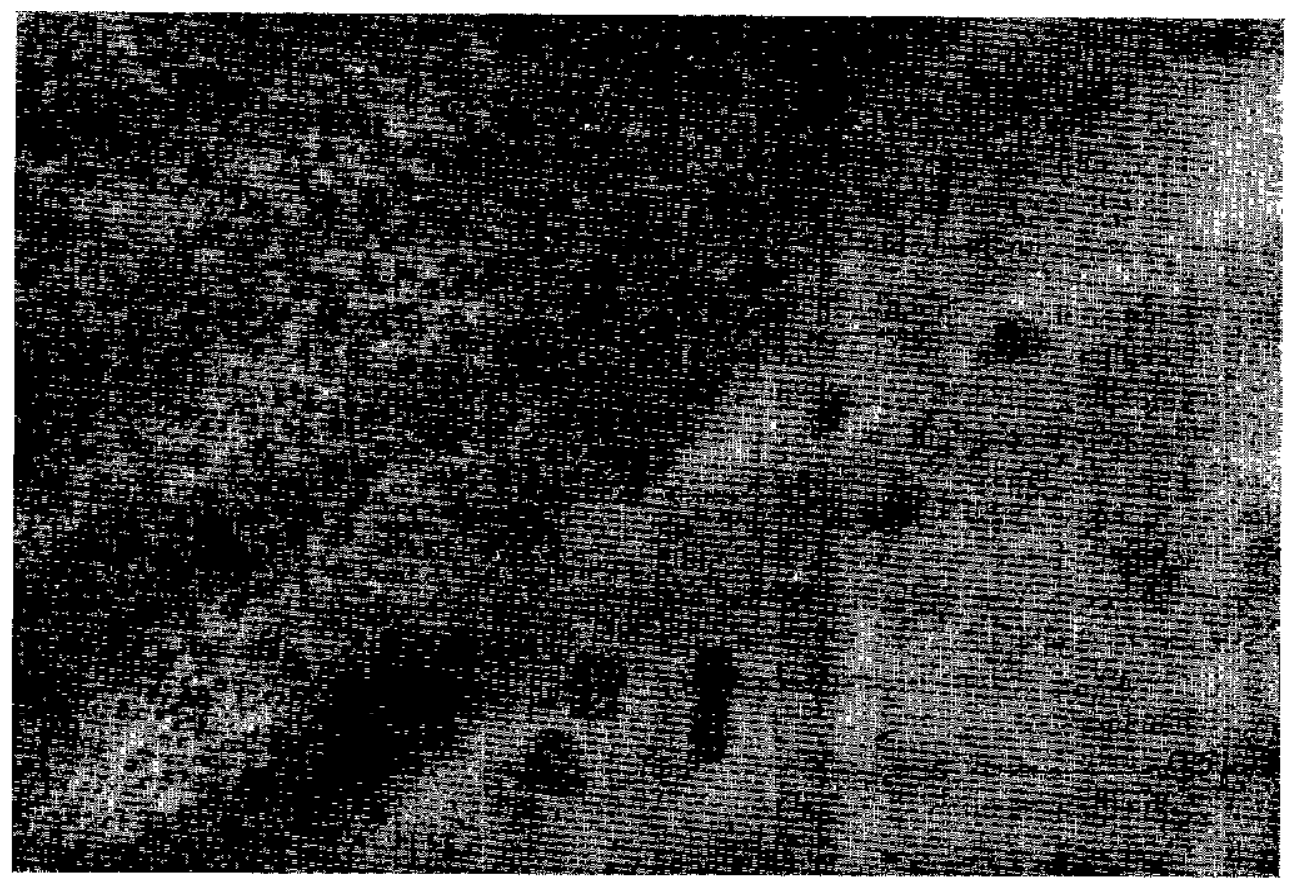

Photo ñ 1. - 30 minutes après l'infection de cellules rénales d'embryon de mouton. Les flèches montrent l'apparent accolement des particules virales à la membrane cellulaire Grossis. : x 30.000.

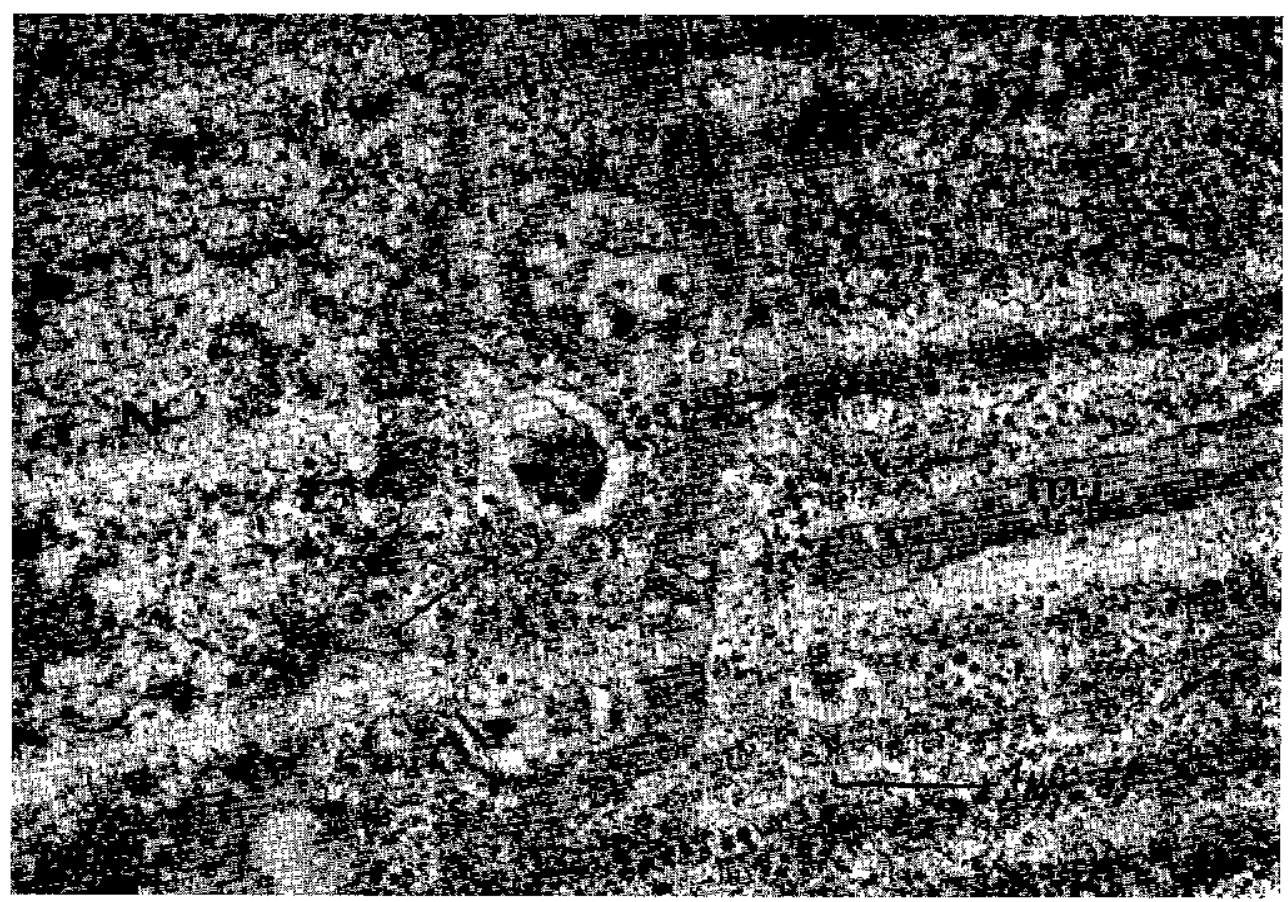

Photo $n^{0} 2$ - à partir de la sixième heure après l'inoculation la cellule est le siège de synthèses intenses, caractérisées par l'abondance des ribosomes (flèches). Le noyau ( $N$ ) ef les mitochondries (Mi) sont intacls. Grossıs. : × 20.000 . 
observé por MANNWEILER (1965) pour le virus de la rougeole, et par PROVOST et coll. (1965) pour le virus de la peste bovine. Ce fait semblerait indiquer que la synthèse des constituants du virus s'effectue à ce niveau. On remarque sur la photo $n^{\circ} 2$ que les mitochondries et le noyau ne présentent pas d'altérations.

A partir de la 12e heure, la membrane cellulaire montre à sa surface des bourgeons dont le nombre va croissant à la 24e et à la 48 e heure (photo $n^{0} 3$ ). Ces formations peuvent exister a la surface des cellules normales mais elles sont alors en petit nombre et ne présentent pas la même structure.

Comme cela a été décrit pour les autres Paramyxovirus et, en particulier par RECZKO ef BOGEL (1962) pour le virus Para-Influenza ef PROVOST, QUEVAL ef BORREDON (1965) pour le virus bovipestique, la sortie du virus PPR à partir de cellules infectées se fait par un bourgeonnement de la membrane cellulaire. La photo ne 3 nous montre la formation de ces bourgeons qui s'étranglent et libèrent les particules virales présentes en grand nombre dans le milieu extérieur.

Ce phénomène de bourgeonnement dure environ jusqu'au $7 \mathrm{e}$ jour, puis va en dimınuant avec la formation des syncytıums; à partir de ce stade, on constate la présence, dans le cytoplasme d'amas de structure filamenteuse, denses aux électrons (photo no 4). Ces amas représentent les inclusions cytoplasmiques décrites par TAJiMA et coll. (1967) pour des cellules rénales d'embryon de veau infectées avec le virus de la peste bovine. D'après ces auteurs ces inclusions seraient des amas d'acide ribonucléıque viral. Dans les cellules contenant de telles inclusions, on observe un arrêt du phénomène de bourgeonnement comme si la membrane cellulare avait subi une altération la rendant inapte à produire du virus. Les acides ribonucléıques ainsi produits et ne pouvant être libérés, s'accumuleraient dans le cytoplasme.

L'examen des cellules infectées, prélevées au $13 \mathrm{e}$ jour montre l'abondance des inclusions cytoplasmiques et en outre, une modification de la partie centrale du noyau caractérisée par une zone moins dense aux électrons que la périphérie. Cette modification de la structure du noyau représenterait les inclusions observées à l'examen optıque (photo no 5 ).

\section{IV. - ÉTUDE CYTOCHIMIQUE DE LA MULTIPLICATION DU VIRUS PPR SUR CULTURES CELLULAIRES}

\section{A) Matériel et méthodes.}

\section{l) Microfluoroscopie :}

On s'est servi de l'orangé d'acridine suivant les techniques de VON BERTALANFFY ET BICKS (1956) et d'ARMSTRONG (1956). L'orangé d'acridine est dilué au $1 / 10.000$ dans un tampon acétate à $\mathrm{pH}$ 4. La coloration se fait immédiatement avant l'observation au microscope à lumière bleue. Le microscope utilisé est un Reichert muni d'une lampe OSRAM NBO 200 ef d'un filtre d'excitation E2-UT $1 / 1,5 \mathrm{~mm}$.

2) Coloration au vert de méthyle-pyronine et test de Brachet :

La technique de coloration au vert de méthylepyronine et le traitement d'une série de lamelles par la ribonucléase au $1 / 5.000$ à $60^{\circ} \mathrm{C}$ sont les techniques employées par BONI\$SOL (1966). La coloration a été faite à $+4^{\circ} \mathrm{C}$ comme le conseille LISON (1960).

3) Réaction nucléole de Feulgen :

La technique classique décrite par LISON (1960) a été utilișée. La fuchsine est du chlorhydrate de parasonaniline.

\section{B) Résultats.}

Comme PALACIOS (1965), en microfluoroscopie, il a été noté une brillance plus forte dans les nucléoles des cellules inoculées. Cette fluorescence plus vive indiquerait une synthèse d'ARN dans les nucléoles due à un transit de I'ARN viral dans ces organites. Cette brillance est visible à partir de la $2^{e}$ heure et disparaît au bout de 32 heures. Pendant les jours suivants, nous $n$ 'avons pu voir de différences entre cellules normales et cellules infectées. Mais à partir du $7 \mathrm{e}$ jour le cytoplasme prend à son tour une fluorescence orange. Dans les polycaryocytes, les inclusions nucléaires et cytoplasmiques ne sont pas fluorescentes.

La coloration des lamelles au vert de méthylepyronine suivie du test de Brachef montre comme pour la coloration à l'orangé d'acridine, une teinte plus vive au niveau des nucléoles à partir de la $2^{\mathrm{e}}$ heure. Cette technique permet de mon- 


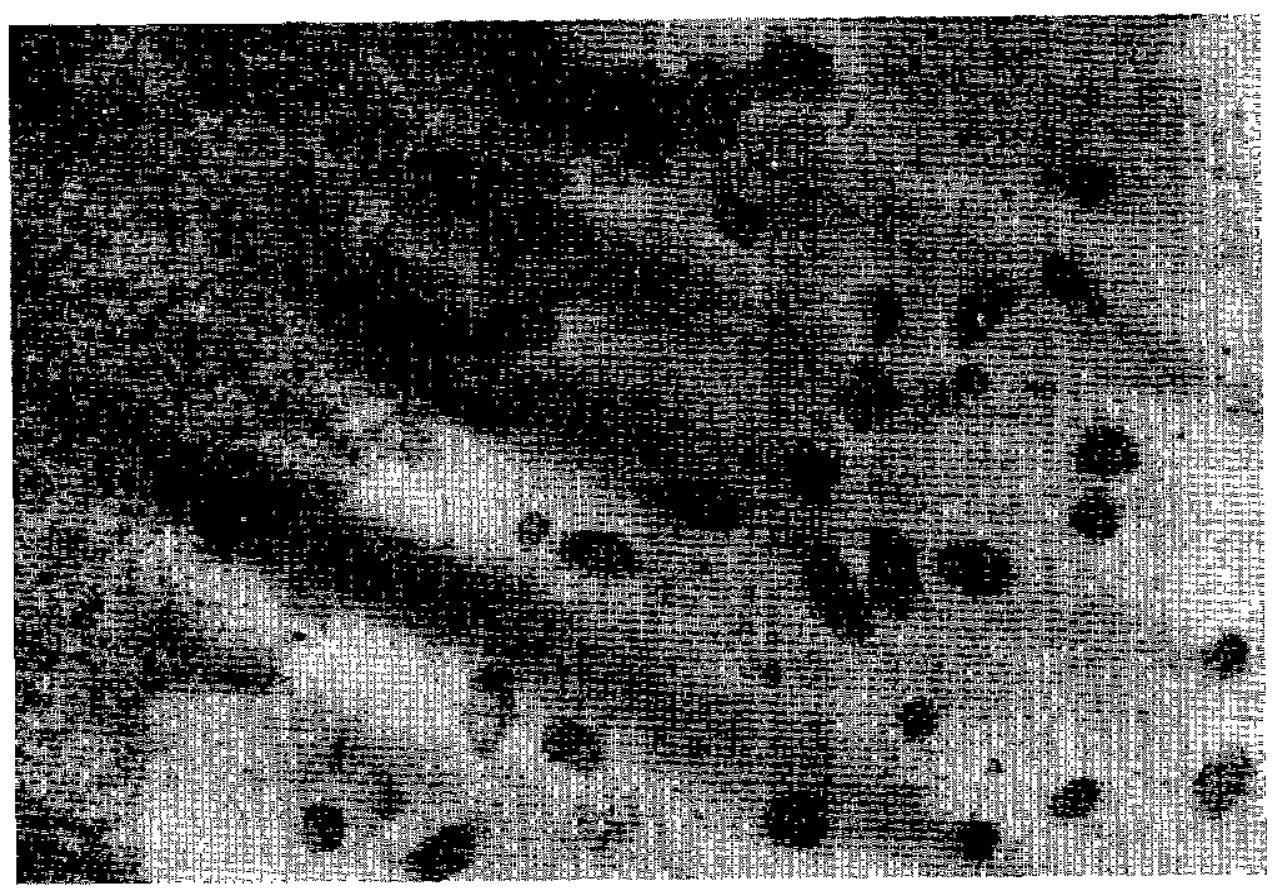

Pholo no 3. - 12 heures après l'infection, le phénomène de bourgeonnement de la cellule commence. Les bourgeons s'étranglent, se scindent et libèrent les particules complètes dans le milieu extérieur (flèches). Grossis. : $\times 20.000$.

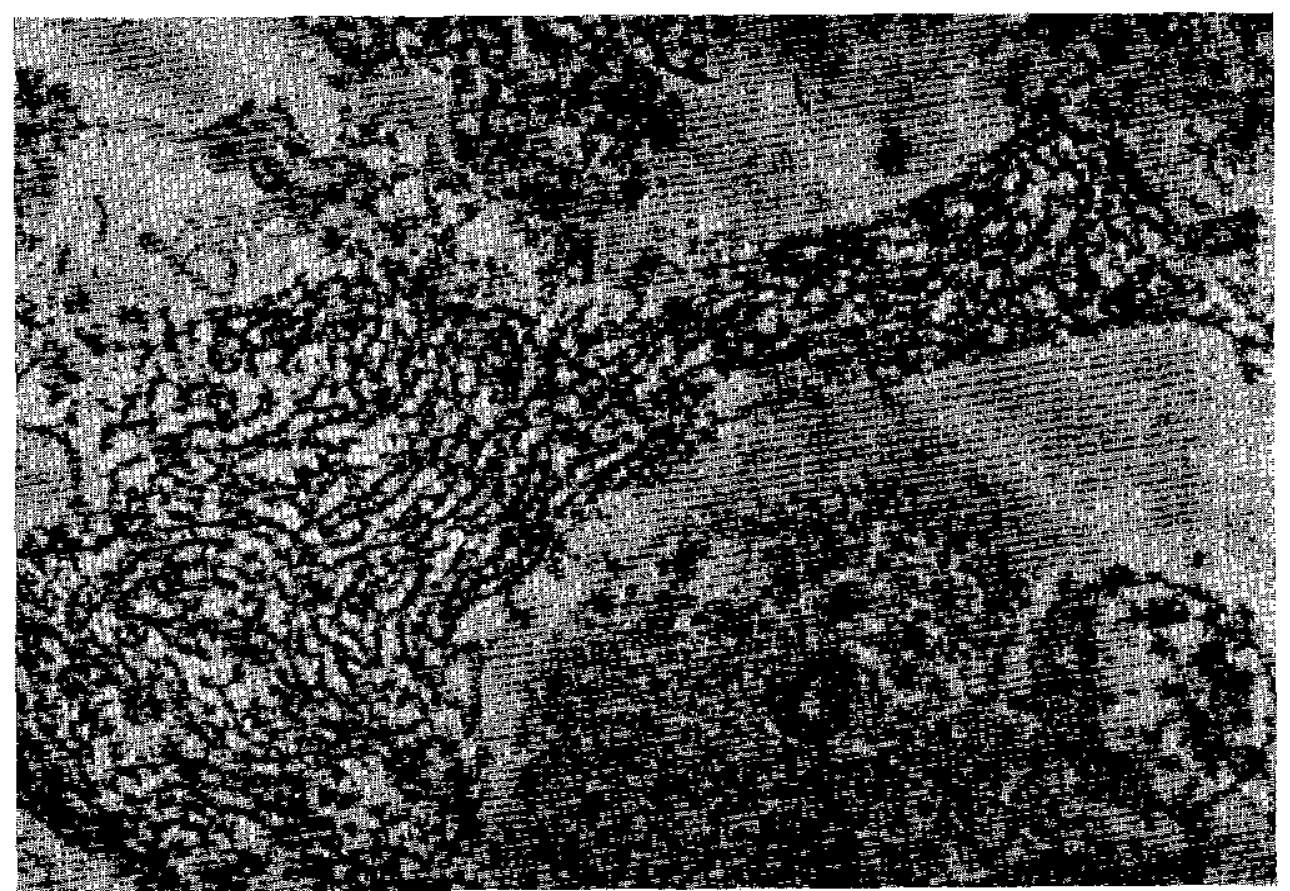

Photo no 4. - Inclusion cyfoplasmique, $\theta$ jours après l'infection. On peut noter l'aspect filamenteux et le contour bien délimité de cette inciusion. Grossis. : $\times 20.000$. 


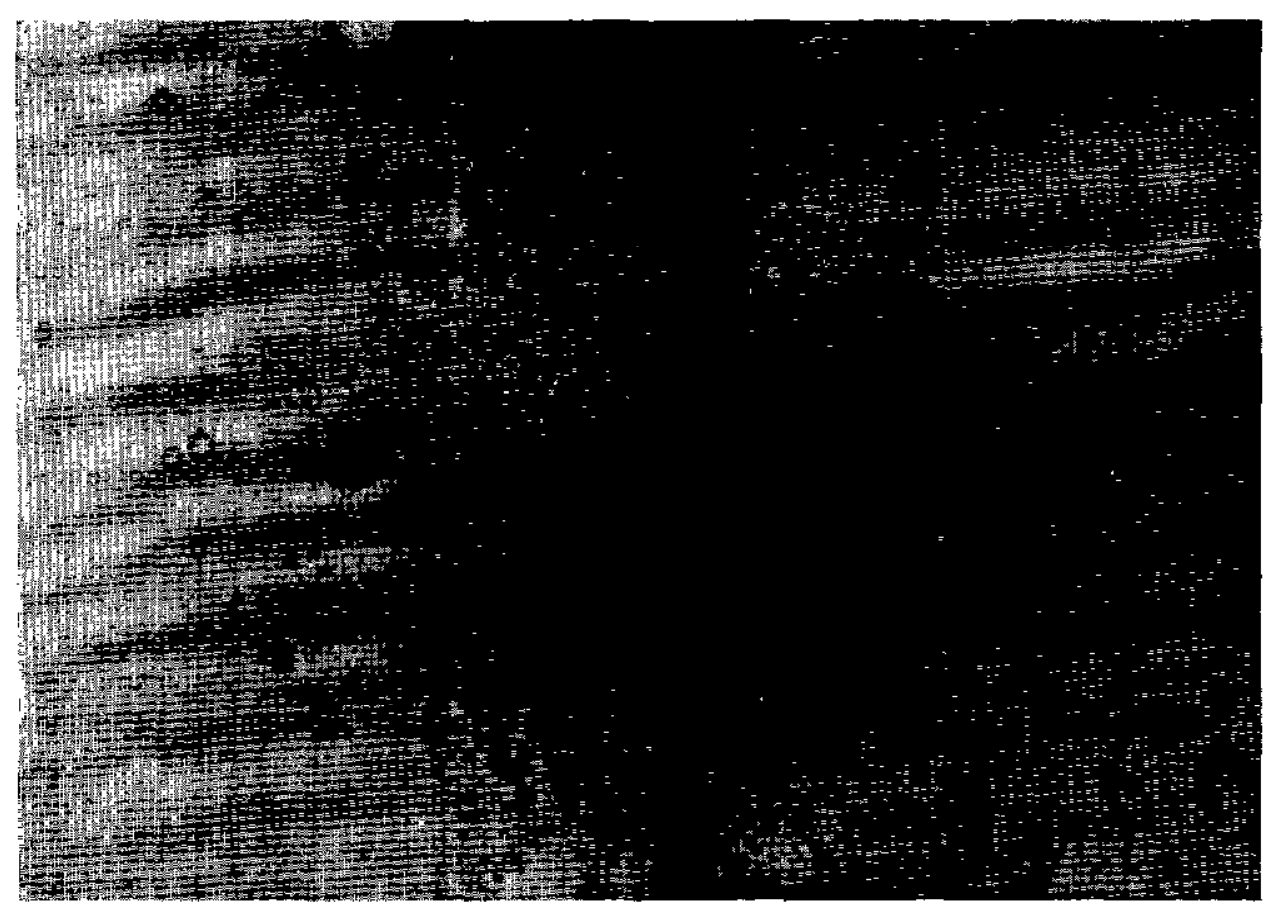

Photo no 5. - Inclusion nucléaíre, 13 jours après l'ínfection. Elle apparaît comme un cercle moins dense aux électrons que la périphérie. Son aspect est très différent de celui de la photo no 4. Grossis. : $\times 7,000$.

trer que les inclusions nucléarres et cytoplasmiques dans les plasmodes sont riches en ARN.

La réaction nucléale de Feulgen a été appliquée sur des lamelles inoculées depuis 8 jours, lorsque l'effet cytopathogène est net. Elle donne une teinte violet-pourpre avec I'ADN. II n'a pas été noté la présence d'ADN ailleurs que dans les noyaux. Ni les inclusions nucléaires, ni les inclusions cytoplasmiques n'en possèdent.

\section{V. - DISCUSSION}

L'étude de l'effet cytopathogène du virus PPR sur cultures cellulaires a montré que celui-ci se multipliait dans les cellules rénales d'embryon de mouton, de veau, de chèvre, dans les cellules rénales de singe, dans les cellules d'amnios humain, dans les lignées cellulaires MS, BHK 21 et MDBKC.

Cette multiplication se traduit par la formation de syncytiums, d'inclusions cytoplasmiques ef nucléaires. Les syncytiums sont plus ou mains importants et d'un aspect différent suivant le type de cellules.
L'examen du virus PPR en microscopie électronique après coloration négative (BOURDIN et LAURENT, 1967) a montré que sa structure était semblable à celle du virus de la peste bovine mas qu'il était de plus grande taille. L'examen des cellules infectées au microscope électronique n'a pas permis d'élucider son mode de pénétration, mais a montré que ces cellules étaient le siège d'une synthèse intense caractérısée par l'abondance des ribosomes et que la sortie du virus se faisait sous la forme de bourgeonnements de la membrane cellulaire.

L'étude des propriétés chimiques amène à conclure que le virus PPR est ınactivé par l'éther, à $\mathrm{pH} 3$ et qu'il n'est pas inhibé par les pyrimidines halogénées.

L'ensemble des résultats obtenus conduit à intégrer le virus PPR dans la classification moderne des virus, mise au point par le CINV (*) en 1966 suivant la systématique de LWOFF,

(*) C.I. N. V. : Comité International de Nomenclature des Virus. 
HORNE ef TOURNIER (1962) de la manıère suivante :

Phylum : vira.

Subphylum : ribovira (virus à ARN)

Classe : Ribohelica (symétrie hélicoidale)

Ordre: Sagovirales (pourvus d'une enveloppe)

Famille : paramyxoviridae

Genre : Paramyxovirus

Espèce type : Para-Influenza.

\section{VI. - CONCLUSION}

Les recherches sérologiques, morphologiques et chimiques permettent de penser que le virus PPR est un virus bovipestique adapté aux petits ruminants. Cependant, dans la biologie de sa multiplication, plusieurs points restent obscurs :

- le mode de pénétration dans la celiule. Malgré l'observation d'un apparent accolement du virus à la membrane cellulaire, de débris, peut-être viraux, dans les vacuoles cytoplasmiques, il n'est pas possible de répondre d̀ cette question : le virus PPR pénètre-t-il dans la cellule vivante par pinocytose ou introduit-il seulement son ARN en laissant son enveloppe vide à l'extérieur?

Pour la suite du cycle de multiplication, l'étude cytochimique permet de supposer que I'ARN viral effectue un transit par le nucléole comme semble le prouver la synthèse de I'ARN au niveau de cet organite.

Cette hypothèse devrait être confirmée par l'emploi de la mytomycine C. NAYAK ef RASMUSSEN (1966) ont montré que la mytomy- cine $C$, qui a la propriété de bloquer l'ADN codant la synthèse de I'ARN, à des concentrations identiques avait une action différente sur deux virus à ARN, la synthèse du virus Influenza étant bloquée, celle du virus de la maladie de Newcastle ne l'étant pas. Ceci laisse supposer que le virus Influenza a un cycle nucléaire et le virus de la maladie de Newcastle, un cycle cytoplasmique.

- L'origine des inclusions nucléaires et cytoplasmiques. Ce dernier stade de la multiplication virale se produit en même temps que la formation des cellules multinuclées. D'après l'étude cytochimique, ces inclusions semblent formées uniquement d'ARN. Au microscope électronique, elles ne présentent pas la même structure. Les inclusions cytoplasmiques ont une structure dense, filamenteuse, une forme variable mais bien délimitée. TAJIMA et coli. (1966) volent en elles une accumulation d'ARN viral. Il est plausible de supposer que cet ARN ne peut se libérer, la membrane cellulaire étant détruite et ne permettant plus la formation de virions complets. Les inclusions nuclécıres sont peu denses aux électrons ; elles résulteraient de la dégradation de la chromatine.

Les techniques d'immunofluorescence et de marquage des antigènes viraux permettraient de suivre avec plus de précision le cheminement de l'acide nucléique viral et de trouver une solution à ces points demeurés obscurs.

Institut d'Elevage ef de Médecine vétérinaire des Pays tropicaux Laboratoire national de l'Elevage ef de Recherches vétérinaires de Dakar-Hann.

\section{SUMMARY}

Biological aspects of the multiplication of Pest of small ruminants virus or P.S. R. on cell cultures

The cylopathogenic effect of P.S.R. virus is shown by syncytiums, nucleal and cytoplasmic unclusions in cells of various origins. This virus is inactivated by ether and at $\mathrm{pH} 3$. Its synthes 15 is not stopped by the 5-iodo-deoxyuridine. Its configuration, as shown by electronic microscope, is similar to that of Rinderpest virus, though its diameter is more impartant. Its penerration has not been evidenced in spite of examination with electronic microscope of the morphology of its multiplication, but the exit is made by the budding of cell-membrane. The cylochemical study suggested that its transit occurs through the nucleolus and 
that the nucleal and cyloplasmic inclusions are made from RNA. These results showed that P. S. R. virus is a myxovirus and suggested some interessing information about its multiplication cycle.

\title{
RESUMEN
}

Aspectos biológicos de la multiplicación del virus de la peste de los pequeéos ruminantes (PPR) sobre los cultivos celulares

\begin{abstract}
Los sincicios, las inclusiones nucieares y citoplasmicas encontrados sobre células de varias origenes resultan de la acción citopalógena del virus PPR. Está inactivado el dicho por el éter y en $\mathrm{pH}$ 3. No se detiene su síntesis por la 5-ioda-deoxiuridina. Su estrúctura estudiada con el microscopio electronico es semejante con la del virus de la peste bovina, aunque su diametro sea más importante. No permitió conocer su modo de penetración la morfologia de su multiplicación examinada en el microscopio electronıco, sino la salida se hace por un brote de la membrana celular.

El estudio citoquimico del virus permite suponer que ésie sigue un tránsito por en medio el nucleolo, y que se forman las inclusiones nucleares y citoplasmicas con el ARN.

Según los resultados obtenidos, el virus PPR sería un paramixovirus, y se emiten hipótesis en cuanto a su ciclo de multiplicación.
\end{abstract}

\section{BIBLIOGRAPHIE}

1. ARMSTRONG (J.). - Histochemical differenciation of nucleic acids by means of induced fluorescence. $J$. of exp. cells res., $1956,1 \mathrm{l}, 1,640$

2. BONISSOL (C.). - Etude de cellules infectées par les Myxovirus Para-Influenza de type 2 et 3 et le virus respiratoire syncytial. II. Etude cytochimique. Ann. Inst. Posteur, 1966, III, 2, 265-281.

3. BOURDIN (P.) et BERNARD (G.). - Application de la méthode de séro-neutralisation cinétique à la recherche des anticorps neutralisants le virus de la peste bovine chez les bovins, les caprins ef les ovins. Rev. Elev. Mćd. Poys trop., 1967, XX, 4, 531-536.

4. BOURDIN (P.) et LAURENT (A.). -- Note sur la structure du virus de la peste des petits ruminants. Rev. Elev. Méd. vét. Pays trop., 1967, XX, 3, 383-386.

5. COMITÉ INTERNATIONAL DE NOMEN CLATURE DES VIRUS, - 9e Congrès de Microbiologie à Moscou, 1966.

6. COMPANS (R. W.), HOLMES (K. V.), SAMUEL (D.) and CHOPPIN (P. W.). An electron microscopic study of moderate and virulent virus cell interactions of the Para-Influenza virus SV5. Virology, 1966, 30, 411-426.

7. DALES (S.) et CHOPPIN (P. W.). - Attachment and penetration of Influenza virus. Virology, 1962, 18, 489-493.

8. GARGADENNEC (L.) et LALANNE (A.). La peste des petits ruminants. Bull. Serv. zootech. Epiz. A. O. F., 1942, 5, 1, 16-21.

9. GILBERT (Y.) et MONNIER (J.). -. Adaptation du virus de la PPR aux cultures cellulaires. Rev. Méd. vét. Pays trop., 1962, 15, 4, 321-335.

10. GILBERT (Y.) et MONNIER (J.). - Rapport annuel de la région de recherches vétérinaires et zootechniques de l'Ouest africain, 1963.

11. JOHNSON (R. H.). - An outbreak of rinderpest involving cattle and sheep. Vet. Rec., 1958, 70, 457-461.

12. LISON (L.). -. Histochimie et cytologie animales. Edit. Gauthier-Villars, 1960.

13. LWOFF (A.), HORNE (R. N.) et TOURNIER ( $P$.) , - Un système des virus. $C . R$. acad. Sci., Paris, 1962, 254, 4225-4227. 
14. MADIN (S. H.) et DARBY (N. B.). - Established kidney cell lines of normal adult bovine and ovine origln. Proc. for the Soc. exp. Biol. and Med., 1958, 98, 574-576.

15. MANNWEILER (K. L.), - Ultrastructural examinations of tissue culture after infection with measles virus. Arch. f. Virusforschung, 1965, 16, 81-96.

16. MORNET (P.), ORUE (J.), GILBERT (Y.), THIERRY (G.) et SAW MAMADOU. - La peste des petits ruminants en Afrique occidentale française. Ses rapports avec la peste bovine. Rev. Elev, méd. vét. Pays trop., 1956, 9, 313-342.

17. NAYAK (D. P.) et RASMUSSEN (F.).influence of mytomycin $C$ on the replication of Inflenza viruses. Virology, 1966, 30, 673-683.

18. OZAWA (Y.). - Studies on the replication of african horse sickness virus in two different cell line cultures. Arch.f. Virusforschung, 1967, XXI, 2, 155-177.

19. PALACIOS (O.). - Cytochemical and fluorescent antibody studies on the growth of measles virus in tissue culture. Arch. $f$. $V$ irusforschung, $1965,16,83-89$.
20. PLOWRIGHT (W.) ef FERRIS (R. D.). Cytopathogenicity of rinderpest virus in tissue culture. Nature, 1957, 179, 316.

21. PROVOST (A.), QUEVAL (R.) et BORREDON (C.). - Quelques recherches fondamentales sur le virus bovipestique. Rev. Elev. méd. vét. Pays trop., 1965, 18, 4, 371-383.

22. RECSKO (E.) et BOGEL (K.), - Electronenmikroskopische untersuchungen uber das verhalten eines von kalb isolierten parainfluenza virus in kalbernnierenzel kulturen. Arch. f. Virusforschung, 1962, 12, 404-420.

23. REED (L. J.) et MUENCH (H.). - Amer. J. Hyg., 1938, 27, 493.

24. STOKER (M.) and MacPHERSON (I.). Syrian hamster fibroblast cell line BHK 21 and its derivatives. Nature, 1964, 203,1355-53.

25. TAJIMA (M.), USHIJIMA (T.), KISHI (S.) and NAKAMURA (J.). - Electron microscopy of cytoplasmic inclusion bodies in cells infected with rinderpest virus. Virology, 1967, 31, 92-100.

26. VON BERTALANFFY (L.) et BICKS (1.). Identification of cytoplasmic basophilis ribonucleic acid by fluorescence microscopy. j. Histochem., 1956, 4, 481-493. 